\title{
Relevansi Strategi Pelipatgandaan Jemaat Berdasarkan 2 Timotius 2:1-13
}

\author{
Winarno \\ Sekolah Tinggi Teologi Berita Hidup \\ win_narno81@yahoo.com
}

\begin{abstract}
What does it mean by multiplication based on II Timothy 2:1-13? What is congregation growth? How relevant is it for today's congregation? Paul gave commandment to Timothy regarding the strategy of multiplying disciples for up to four generation in II Timothy 2:2, this showed that Paul as a spritual parent or mentor duplicate timothy as the second generation and Timothy will entrust the multiplication to those reliable to teach other to grow and become the forth generation of Paul. The relevance of today's congregation means to train and prepared the congregation to be disciples. The first generation takes important role specially the pastor who leads the church to give equipment through the teaching and evangelism training and emphasize the characteristic of a disciple. Assisting and supporting in prayer is also needed for the next generation up to the four generation so that there is multiplication movement of congregation that become the disciple of Jesus Christ.
\end{abstract}

Keywords: disciple, multiplication, the growth of congregation

\begin{abstract}
Abstrak: Apakah yang dimaksud pelipatgandaan berdasarkan II Timotius 2:1-13 ?, dan apa itu pertumbuhan jemaat? Serta bagaimana relevansinya bagi jemaat masa kini? Paulus memberikan perintah kepada Timotius berkaitan dengan strategi pelipatgandaan murid sampai empat generasi dalam II Timotius 2:2, ini menunjukkan bahwa mulai dari Paulus sebagai orang tua rohani atau mentor melipatgandakan Timotius sebagai generasi kedua dari Paulus, kemudian Timotius mempercayakan lagi atau melipatgandakan lagi yaitu orang yang dapat dipercayai sebagai generasi ketiga dan berikutnya orang yang dapat dipercayai mengajar orang lain untuk bertumbuh yang menjadi generasi keempat dari Paulus. Relevansinya pada jemaat masa kini, berarti jemaat harus dilatih atau disiapkan untuk menjadi murid, dan peran generasi pertama sangat penting disini, yaitu peran gembala yang memimpin gereja dengan memberikan perlengkapan-perlengkapan melalui pengajaran dan pembimbingan serta melalui pelatihan-pelatihan penginjilan serta terus menekankan tentang karakter murid, dan melakukan pendampingan juga memberikan dukungan doa pada generasi berikutnya, sampai generasi yang keempat sehingga terjadi gerakan pelipatgandaan jemaat yang menjadi murid Tuhan Yesus Kristus.
\end{abstract}

Kata Kunci: murid, pelipatgandaan, pertumbuhan jemaat

\section{PENDAHULUAN}

Gereja mana yang tidak ingin mengalami pertumbuhan jemaat baik secara kuantitas ataupun kualitas. Jemaat yang bertumbuh merupakan indikasi bahwa program yang dibuat oleh gereja tersebut berhasil. "Bila gereja tidak bertumbuh maka hal ini akan memberi dampak yang negatif bagi perkembangan gereja itu sendiri dan masalah terbesarnya adalah gereja bisa menjadi sekarat." ${ }^{1}$ Tentunya banyak masalah yang melatarbelakangi masalah

${ }^{1}$ Rick Warren, Pertumbuhan Gereja Masa Kini, (Malang: Gandum Mas, 1995), 20. 
pertumbuhan tersebut berkaitan dengan pelipatgandaan, padahal Alkitab banyak memberikan contoh tentang bagaimana jemaat dapat bertumbuh bahkan akhirnya bisa melipatgandakan. Hal tersebut bisa dilihat mulai dari pelayanan Tuhan Yesus sendiri yang memberikan teladan lewat pelayanannya kepada para murid hingga bisa berlipat ganda sampai menjadi seperti saat sekarang ini. Demikian juga pengajaran Paulus kepada Timotius dalam suratnya kepada Timotius untuk bisa memsercayakan lagi tongkat estafet pelayanan kepada orang lain lagi yang dapat dipercaya (2 Tim. 2:2).

Jemaat tidak bertumbuh dengan pelipatgandaan karena belum mengerti prinsip mendasar dari pelipatgandaan dalam 2 Timotius 2:2, sehingga jemaat pasti belum melakukan langkah yang pertama untuk melipatgandakan yaitu tidak menginjil. Padahal waktu itu Tuhan Yesus memberikan contoh lewat perkataan "ikutlah aku" seperti diungkapkan oleh Peter Lyne sebagai berikut:

Jadi, ketika Yesus berkata, "ikutlah Aku" pada sekelompok nelayan, pemungut cukai dan lainnya, dan mereka mulai berkeliling desa bersama-sama, menginap diberbagai rumah dan kadangkala berkemah di udara terbuka karena tidak memiliki tempat untuk membaringkan kepala, Yesus sedang menunjukkan suatu model kepemimpinan yang masih sangat penting bagi masa kini. ${ }^{2}$

Penginjilan merupakan kunci pertama untuk menuju kepada pelipatgandaan jemaat yang tentunya juga harus didukung dengan doa $^{3}$, karena diibaratkan penginjilan dengan doa adalah seperti anak panah dengan busurnya. Penginjilan merupakan amanat bagi setiap orang yang percaya seperti yang diperintahkan Tuhan Yesus dalam Matius 28 :19-20, yang dikenal dengan Amanat Agung. ${ }^{4}$

Sebuah gereja mungkin menunjukkan pertumbuhan baru yang pesat, tetapi tidak semua pertambahan ini berasal dari orang Kristen baru. Hal ini dapat disebabkan karena jemaat belum tahu cara melipatgandakan. Gereja belum memiliki program untuk memperlengkapi jemaat dengan alat supaya jemaat bisa melipatgandakan. Gereja harus dapat memberdayakan jemaatnya melalui pemanfaatan fungsi karunia-karunia Roh untuk dapat menyesuaikan tantangan misi yang ada di zamannya. ${ }^{5}$ Banyak gereja lupa seperti kisah Pendeta James Kennedy sebagai pendiri Evangelism Explosion, yang hanya terus memotivasi jemaat untuk memberitakan injil tanpa memberikan metode atau alatnya, ini sama dengan menyuruh prajurit bertempur tanpa membekali dengan senjata. "Sebelum melibatkan kaum awam/jemaat untuk penginjilan atau memenangkan orang bedosa bagi Kristus tentu membutuhkan persiapan terlebih dahulu melalui pelatihan-pelatihan. ${ }^{6}$

Ada banyak cara yang dilakukan gereja untuk melakukan pelipatgandaan, mulai dengan program pemuridan atau kelas-kelas pelatihan dan strategi lainnya. Artikel ini

\footnotetext{
${ }^{2}$ Peter Lyne, Peralihan Tongkat, (Jakarta: Yayasan Pekabaran Injil Immanuel, 2002), hal 26

${ }^{3}$ Wiryadinata, "Mission And Evangelism : African Context."

${ }^{4}$ Dwiraharjo, "Kajian Eksegetikal Amanat Agung Menurut Matius 28 : 18-20."

${ }^{5}$ Harls Evan R. Siahaan, “Aktualisasi Pelayanan Karunia Di Era Digital," EPIGRAPHE: Jurnal Teologi dan Pelayanan Kristiani 1, no. 1 (2017): 23-38, www.stttorsina.ac.id/jurnal/index.php/epigraphe.

${ }^{6}$ Cara Gereja Lokal Dapat Bertumbuh Secara Sehat, available from, http://www.sabda.org/PUBLIKASI/a31-misipenginjilan.blogspot.com. Internet
} 
memberikan penekanan pada pola yang diajarkan oleh Paulus kepada Timotius sebagai cara yang dapat digunakan oleh gereja pada masa kini.

\section{METODOLOGI}

Artikel ini merupakan penelitian kualitatif dengan menggunakan metode analisis deskriptif pada teks Alkitab dalam 2 Timotius 2:1-13. Nas tersebut dideskripsikan sesuai dengan proses hermeneutik sehingga didapatkan pemahaman yang dapat diterapkan dalam pelayanan gerejawi masa kini. Paulus mengatakan bahwa apa yang telah engkau dengar dari padaku di depan banyak saksi, untuk kembali mempercayakan kembali tetapi bukan kepada sembarang orang, tetapi mempercayakan lagi kepada orang-orang yang dapat dipercayai dan cakap mengajar orang lain lagi."

Ayat 2 berbunyi: Apa yang telah engkau dengar dari padaku di depan banyak saksi, percayakanlah itu kepada orang-orang yang dapat dipercayai, yang juga cakap mengajar orang lain. Ayat 2 dalam ini tidak bisa dipisahkan dari ayat 1; ini bisa dilihat dengan dimulai subyek anakku (téknon), yang menunjuk pada Timotius sendiri, untuk menjadi kuat (endunamoú) dan percayakanlah (paráthou). Timotius harus menjadi kuat tetapi oleh karena anugerah yang dari Tuhan Yesus Kristus, bukan dengan usaha atau kehebatan Timotius. Dari bagian ini memberikan penjelasan bahwa ketika Timotius mempercayakan kondisinya juga harus menjadi kuat, ini menunjukkan bahwa kedua hal tersebut dilakukan bersama-sama atau dengan kata lain ada sebuah keteladanan ketika mempercayakan.

Penting untuk melihat kata kerja yang ada dalam II Timotius 2:1-2 ini agar memperoleh pemhaman yang lebih jelas lagi tentang apa yang seharusnya dilakukan oleh Timotius ketika hendak melakukan pelipatgandaan. Paling tidak ada lima tahapan yang harus dilakukan yang semuanya berbentuk dalam kata kerja, yaitu:

\section{Menjadi Kuat Lebih Dulu}

Himbauan tersebut terkadung dalam kata "jadilah kuat" Ketika dilihat dalam bahasa Indonesia kata ini sepertinya memberikan arti supaya Timotius berusaha dengan sekuat tenaga, daya dan upayanya supaya dia menjadi kuat, dalam konteks ini tentunya menjadi kuat dalam melayani Tuhan dan Jemaat Efesus yang dipercayakan kepadanya. Padahal di sinlah Paulus sedang memberikan dorongan kepada Timotius supaya terus-menerus secara konstan dan memiliki ketekunan dalam pekerjaan yang dilakukan.

Dalam bahasa Yunani digunakan kata endunamou yang secara gramatikal berarti "to give power," "to make strong," "to strengthen" (memberi kekuatan, membuat menjadi kuat, atau menjadikan kuat). Ini menunjukkan upaya aktif si pelaku, yaitu Timotius yang menjadi kuat karena anugerah yang dari Tuhan Yesus Kristus. Kata "dikuatkanlah" dipakai dalam Alkitab sebanyak 7 kali, dan kata yang sama juga digunakan dalam Filipi 4:13 Segala perkara dapat kutanggung di dalam Dia yang memberi kekuatan kepadaku. ${ }^{7}$ Sehingga menjadi jelas bahwa kata "jadilah kuat" memiliki pengertian ada yang memberi kekuatan.

\footnotetext{
${ }^{7}$ Hasan Sutanto, Perjanjian Baru Interlinier Yunani-Indonesia, (Jakarta: LAI, 2003), 1129
} 


\section{Mendengar dengan Saksama}

Hal tersebut tercermin dalam kata "dengar" yang dalam bahasa Yunani kata yang dipakai yaitu (eékousas) yang berasal dari kata dasar ókoúw (akouo), yang dalam Alkitab muncul sebanyak 428 kali. $^{8}$ Kata ákoú $\omega$ (akouo) ini berarti mendengar, mendengarkan, mendengar (dalam pemeriksaan perkara), mengetahui, menaati dan mengerti. Bahkan disebutkan artinya "to give ear to a teaching or a teacher" ini sama artinya dengan memberi telinga untuk diajar guru, atau dengan kata lain memperhatikan dengan sungguh-sungguh supaya mengerti apa yang diajarkan oleh guru.

Dari penjelasan secara gramatikal tersebut bisa dilihat bahwa kata "engkau dengar" bukan hanya sekedar lewat saja dan bukan hanya mendengar yang seperlunya, atau bahkan yang penting sudah mendengar, tetapi mendengar dalam kata aslinya berarti Timotius melakukan aktifitas atau pekerjaan mendengar yang sungguh- sunguh bahkan hanya menyiapkan telinganya untuk mendengarkan gurunya saja dan itu berarti mengabaikan untuk mendengarkan hal yang lain, dan mendengar ini direalisasikan atau dipraktekkan oleh Timotius.

Pertanyaannya apa yang didengar oleh Timotius dari Paulus sampai harus membutuhkan konsentrasi yang terfokus itu? untuk itu harus melihat kepada pasal sebelumnya di pasal yang 1:6-11. Pengajaran yang luar biasa yang telah diajarkan Paulus kepada anak yang dikasihinya Timotius, yang memberikan pengharapan yang luar biasa bagi manusia yang seharusnya dimurkai dan dibinasakan tetapi oleh karena kasih karunianya jaman sekarang manusia boleh ditebus dan diselamatkan bahkan berhak untuk memiliki hidup yang kekal oleh karena kuasa Injil yang telah mematahkan kuasa maut.

\section{Keberanian untuk Memercayakan}

Bukanlah hal mudah untuk mempercayakan apa yang telah dimiliki oleh seseorang untuk mempercayakan lagi kepada orang lain. Hal tersebut terdapat dalam kata “percayakanlah" (paráthou) ${ }^{9}$ dari akar kata $\pi \alpha \rho \alpha \tau i ́ \theta \eta \mu$ (paratithemi). Kata ini muncul 19 kali dalam Alkitab, yang berarti menaruh di depan, membentangkan di depan, menyerahkan, atau membuktikan. NIV, NAS dan RSV menggunakan kata "entrust" (dipercaya). Sedangkan menurut KJV berarti "same commit" (memiliki komitmen yang sama). Kata "percayakanlah" berarti bahwa percayakanlah itu adalah memberikan kepada orang yang memiliki komitmen yang sama yaitu orang yang terpercaya. Hal ini memberikan pengertian bahwa kata "percayakanlan" berarti memberikan kepada orang yang memiliki komitmen yang sama, dan ketika orang yang melihat orang yang dipercayakan itu seolah-oleh dia melihat gambaran orang yang pertama kali melakukannya atau aslinya.

Dalam kata inilah yang disebut dengan multiplikasi ini muncul, apa sebenarnya makna multiplikasi pribadi itu sendiri, multiplikasi pribadi adalah "proses duplikasi,

\footnotetext{
${ }^{8}$ Ibid

${ }^{9}$ Ibid
} 
kelipatan yang berlangsung terus-menerus."10 Jadi kata percayakanlah yang berarti juga mempercayakan atau menyerahkan itu mengandung pengertian bahwa orang yang diserahkan adalah duplikat dari orang yang menyerahkan sehingga benarlah pengertian tadi menggambarkan aslinya, karena yang namanya duplikat itu adalah mirip aslinya, tetapi memang bukan aslinya. Kalau melihat dalam Matius 28 bisa dilihat proses multiplikasi ini, yaitu :

Murid pergi menjadikan murid $=$ Duplikasi

11 murid jadikan semua bangsa murid = Kelipatan

Ajarlah mereka melakukan ... = terus-menerus.

\section{Memiliki Kemampuan untuk Mengajar}

Kata "Mengajar" dalam bahasa yunani menggunakan (didáxai) ${ }^{11}$ yang berasal dari akar kata $\delta ı \delta$ ó $\sigma \kappa \omega$ (didasko), yang memiliki arti to learn; to teach. Kata mengajar yang dimaksudkan di dalam ayat ini sama dengan kata yang diapakai Yesus ketika mengajar waktu berkeliling ke Galilea (Mat. 4:23). Kata ini dalam 2 Timotius 2:2, memberikan pemahaman bahwa orang yang mau mengajar orang lain adalah orang yang sudah mengusai materi yang akan diajarkan dan juga tentunya sudah berpengalaman dengan bidang yang akan diajarkan tersebut. Untuk memiliki pengalaman bidang tersebut berarti sang pengajar harus sudah mempraktikkan apa yang akan diajarkan. Sebagai contoh kalau seorang mau menjadi pengajar dalam bidang penginjilan, maka sang pengajar harus mengusai seluk-beluk materi tentang penginjilan yang akan diajarkan, kemudian yang berikutnya berarti sang pengajar harus memiliki pengalaman.

Agar Timotius bisa mempercayakan apa yang telah didengar dari Paulus, yaitu pengajaran yang disebutkan dalam pasal 1:6-11, maka ada hal yang dilakukan secara bersamaan adalah: Timotius harus juga menjadi kuat atau tetap terus memiliki kekuatan dalam melayani Tuhan, kekuatan dalam menjadi teladan. Kekuatan itu sendiri dijelaskan bahwa berasal dari anugerah Tuhan Yesus Kristus, bukan karena kesalehan atau usaha dari Timotius. Hal ini bukan berarti juga Timotius hanya pasif dan berdiam diri tanpa melakukan apa pun, melainkantetap setia mengerjakan pelayanannya masing-masing.

Setelah Timotius terus dikuatkan dalam frasa jadilah kuat, maka tinggal tugas yang bersamaan harus dilakukan yaitu percayakanlah atau serahkanlah atau mempercakan hal yang sama yang telah didengarnya dan dipahaminya dari instrukturnya atau mentor rohaninya yaitu Rasul Paulus yang juga pasti sudah dilakukannya tadi ketika Timotius diberi kekuatan oleh anugerah dari Tuhan Yesus Kristus dalam mempraktikkan untuk memperoleh pengalaman-pengalaman sebagai sebuah persiapan untuk mempercayakan kepada orang lain lagi.

\footnotetext{
${ }^{10}$ Guntar Maniku, Buku ledakan pemuridan di Gereja Lokal, 3

${ }^{11}$ (Interlinear Transliterated Bible. Copyright (C) 1994, 2003, 2006 by Biblesoft, Inc. All rights reserved. [For more detail see the full copyright page.])
} 
Hal-hal yang Timotius lakukan terhadap orang lain tentang apa yang telah ia dengar tentang rasul di antara banyak saksi; Dia juga tidak boleh memberikan apapun selain itu, dan apa yang Paulus sampaikan kepadanya dan orang-orang lain yang dia terima dari Tuhan Yesus Kristus, berarti Timotius harus menjadi teladan terlebih dahulu. Oleh sebab itu ditengah segala hal yang dialami dalam pelayan Timotius dinggatkan oleh Paulus untuk Timotius tetap menjadi teladan bagi orang percaya dalam tingkah laku, dalam kasih dan dalam kesetiaan serta dalam kesucian (1 Tim. 4:12), supaya sekalipun dia muda tidak dianggap remeh oleh para senior atau orang yang lebih tua dan mungkin memiliki lebih banyak pengalaman.

Ternyata Paulus punya pola yang sama seperti yang Yesus lakukan untuk mempersiapkan mempersiapkan generasi keempat (Yoh 17: 9 dan 20), Yesus berdoa bukan untuk dunia tetapi untuk murid-muridnya yang dua belas dan mungkin ada tambahan yang lain, tetapi kembali di ayat 20 berdoa bagi orang yang percaya kepada Tuhan Yesus oleh pemberitaan murid-murid tadi. Demikan juga dengan Paulus "memuridkan Timotius tidaklah cukup. Paulus mengharapkan Timotius meneruskan "apa yang telah ia dengar" kepada orang-orang yang dapat dipercayai, yang juga pandai mengajar orang lain-reproduksi rohani.",12

Setelah Timotius diberikan kekuatan dan juga mempercayakan kepada orang lain maka tiba saatnya juga Timotius harus memberikan mentoring kepada orang -orang yang dipercayai oleh Timotius untuk melakukan hal yang sama seperti yang telah dilakukan oleh Timotius dibawah mentoring Paulus, Timotius harus menjadikan mereka sebagai kepercayaan, sebagai simpanan atau bekal suci, yang harus mereka simpan, dan untuk mentransmisikan yang murni dan tidak berkorupsi kepada orang lain. ini berarti Timotius menjadi instruktur dari orang-orang yang dipercayai untuk boleh mendapatkan pemahaman yang baik tentang apa yang diajarkan oleh Timotius dan memperoleh pengalaman sebanyak mungkin dalam melayani Tuhan dan disitulah hal yang sama akan dialami oleh orang tersebut yaitu dikuatkan oleh Tuhan Yesus sendiri.

Demikian juga orang-orang yang telah dipercayai tadi adalah orang-orang yang juga cakap mengajar orang lain lagi, jadi bukan orang yang sembarangan orang yang dipercayai tetapi orang yang memiliki ketrampilan atau kelebihan untuk mengajar lagi kepada orang-orang lain. Ternyata kriteria pertama yang dipercayai adalah orang yang cakap. Kata cakap itu berarti bukan hanya bisa tetapi betul betul terampil, bukan hanya mengusai secara teori tetapi dalam praktekpun terampil, dan untuk menjadi terampil atau cakap ini butuh pengalaman-pengalaman dan terus melakukan latihan. Seperti contoh untuk menjadi seorang atlit pemanah yang terampil atau cakap maka setiap waktu harus terus belajar mengarahkan anak panahnya ke sasaran yang dituju. Ketika baru pertama memanah sudah bisa dipastikan tidak mungkin bisa memanah tepat ditengah bulatan yang dituju, tetapi dengan banyak dan tekun berlatih maka pada akhirnya sang pemanah tersebut dapat terampil untuk mengarahkan panahnya ke sasaran tengah. Dan memang

\footnotetext{
${ }^{12}$ Scott Morton, Pemuridan untuk semua orang, (Yogyakarta: Yayasan Gloria, 2011), 131
} 
betul betul harus fokus dalam bidangnya tersebut, kalau memang ingin seorang atlet panahan menjadi handal atau cakap berarti hampir sebagian besar waktunya dihabiskan untuk berlatih panahan.

Ternyata ketika dicermati ayat ini menunjukkan adanya sebuah perintah untuk bermultipilkasi, Maniku mengatakan "Kita banyak berhasil melatih murid tetapi kurang fokus untuk melatih murid-murid baru yang sanggup untuk melatih murid-murid lainnya. (2 Tim 2:2). Kita baru tiba pada proses produksi, tetapi belum bereproduksi."13 Jadi Paulus menduplikasikan dirinya dalam Timotius, kemudian berlipatganda lagi Timotius menduplikasikan dirinya kepada orang-orang yang dapat dipercayai dan proses terus berjalan kepada orang-orang yang dapat dipercayai yang cakap mengajar menduplikasikan dirinya kepada orang lain, dan proses tersebut akan terus berjalan.

\section{Karakter Yang Siap Melipatgandakan Menurut II Timotius 2:3-7}

Herdy mengatakan tentang Paulus seperti berikut:

Rasul Paulus adalah seorang mentor yang luar biasa. Ia melatih anak rohaninya, Timotius, dengan baik. Ia mengajarkan prinsip-prinsip kebenaran Firman Tuhan. Jadi ketika Paulus mengamati bahwa pertumbuhan Timotius sudah siap, ia memberikan kepercayaan baginya untuk memuridkan dan mementor orang lain yang dapat dipercaya agar pada suatu saat kelak orang tersebut juga memuridkan atau mementor orang-orang lain. ${ }^{14}$

Itu sebabnya Paulus menasihati Timotius mengenai beberapa karakter yang harus dimiliki oleh seorang yang akan melakukan pelipatgandaan melalui perumpamaan pekerjaan.

\section{Menjadi Seperti Seorang Prajurit}

Dalam 2 Timotius 2:3 Paulus menasihati Timotius untuk siap menderita sebagai seorang prajurit yang baik. Seorang prajurit pada masa itu yaitu prajurit Romawi adalah orang yang memiliki kesetiaan mutlak kepada atasannya dan apapun yang diperintahkan oleh atasannya atau komandannya tidak ada kata lain selain "siap laksanakan." Tenney juga menjelaskan lewat maksud perumpamaan prajurit bahwa Paulus ingin mendorong Timotius, agar menerima segala kesulitan seperti seorang prajurit yang maju berperang (2:3), dengan memasrahkan perencanaan strategi pada pimpinannya, dan mengabdi sepenuh hati dan tanpa pernah mengeluh di mana pun tenaganya dibutuhkan. ${ }^{15}$

Seorang prajurit yang sedang berperang kalau ingin menang seharusnya fokusnya di medan pertempuran tersebut, karena kalau prajurit tersebut lengah di dalam medan peperangan maka bisa jadi prajurit tersebut mengalami kekalahan atau terluka oleh senjata lawan. Apalagi sempat berfikir tentang penghidupannya, pastilah makin fatal. Memang menderita ketika sedang bertempur tetapi ketika menang akan jadi pahlawan, seperti yang Tuhan Yesus alami ketika menebus manusia yang berdosa seperti yang ungkapkan oleh Randy bahwa "drama penebusan yang telah disingkapkan adalah kisah paling hebat yang

\footnotetext{
${ }^{13}$ Guntar Maniku, Bahan Amanat Agung dalam perspektif Multiplikasi Pribadi, 7

${ }^{14}$ Herdy N. Hutabarat, Mentoring dan Pemuridan, (Bangdung: Yayasan Kalam Hidup, 2011), 200.

${ }^{15}$ Merrill c.Tenney, Survei Perjanjian Baru, (Malang: Gandum Mas, 2001), 421
} 
pernah diceritakan. Yesus adalah pahlawan, yang amat sangat menderita, tetapi pada akhirnya menang. “16

Ketika prajurit tersebut fokus dalam pertempurannya dan mengikuti instruksi strategi dari komandannya pastilah komandannya akan berkenan dengan prajurit tersebut,tetapi ketika prajurit tersebut sibuk dengan penghidupannya, mungkin berfikir tentang bagaimana makannya, atau berfikir bagaimana keluarganya maka yang terjadi adalah prajurit tersebut tidak jadi bertempur atau melarikan diri dari medan pertempuran. Dan yang didapat prajurit tersebut justru akan mendapat hukuman dari komandannya dan yang paling fatal pastilah akan dikeluarkan dari kesatuannya. Hal yang paling pokok yang bisa dilihat dari seorang prajurit adalah ketaatannya, seperti "Yesus memberikan contoh dalam hal setia pada panggilanNya untuk memikul tanggungjawab yaitu menderita, bahkan sampai mati di kayu salib untuk menebus dosa-dosa kita. ${ }^{17}$ Ketaatan Tuhan Yesus luar biasa karena Yesus tidak bisa menolak apa yang diperintahkan Bapa kepadaNya, sehingga Yesus hanya seperti Prajurit yang diperintahkan oleh komandannya dan hanya berkata "siap laksanakan", dengan bahasa yang disampaikan biarlah kehendakMu yang jadi.

Demikian yang Paulus pesankan kepada Timotius lewat gambaran seorang prajurit, untuk tetap memiliki ketaatan yang mutlak kepada komandannya yaitu Tuhan Yesus sebagai Kepala. Tetapi berapa sering orang percaya yang kurang taat dengan Tuhan Yesus hanya karena masalah penghidupannya? Padahal seharusnya lebih taat ketika mengalami masa masa sukar seperti " nasihat yang disampaikan penulis kitab Ibrani sehubungan dengan peningkatan iman adalah memikirkan kembali masa-masa sukar di dalam hidup kita (Ibrani 10:32-35)."18

John menjelaskan seperti berikut:

Jelas orang-orang Yahudi yang menerima surat itu telah melewati pengalaman yang mendorong pertumbuhan dalam penderitaan mereka. Kebesaran dan kedaulatan Tuhan makin mereka rasakan. Pengalaman mereka di dalam Kristus menjadi begitu menggairahkan. Karenanya, sekalipun kenangan mereka dibungkus oleh penderitaan, kenangan itu berharga. Ketika bungkusan penderitaan sudah tidak ada lagi dan kenangan itu dihidupkan hati merekapun kembali bergelora oleh kasih dan kesetiaan pada Kristus. Iman mereka dibangkitkan lagi. ${ }^{19}$

Dan inilah juga karakter yang harus dimiliki oleh orang yang akan dipersiapkan untuk bisa melipatgandakan pelayan atau prajurit Kristus yang lainnya.

\section{Menjadi Seperti Seorang Petani}

Seorang petani ketika sedang menyebar bibit padi, maka tidak mungkin besoknya bisa melihat bibit itu tumbuh, apalagi dalam waktu seminggu mengharap panen dari padinya. Tetapi petani tersebut setia dan sabar untuk menunggu waktu dengan tekun mengerjakan proses menyebar bibit padi, sampai menanam bahkan merawat sampai

\footnotetext{
${ }^{16}$ Randy Alcon, Dalam Terang Kekekalan ( Yogyakarta: Yayasan Gloria-katalis, 2011), 247-248

${ }^{17}$ Herdy N. Hutabarat, Mentoring dan Pemuridan, (Bandung: Yayasan Kalam Hidup, 2011), 189.

18 John White, The Fight, (Yogyakarta: Yayasan Gloria, 2011), 112

${ }^{19}$ Ibid, 113
} 
akhirnya melihat hasilnya atau menuai padi tersebut. Untuk bersabar seperti gambaran petani bukanlah hal yang mudah, tetapi beberapa kali Rasul Paulus juga menuliskan hal ini seperti yang ditulis oleh Bridges seperti berikut:

Rasul Paulus, dalam beberapa suratnya, menasihati kita untuk bersabar. Dalam 1 Korintus 13, pasal yang agung tentang kasih "kasih," ia mengawali deskripsinya tentang kasih dengan mengatakan, "kasih itu sabar." Dalam Galatia 5:22-23, kesabaran adalah salah satu dari sembilan ekspresi buah roh. Dalam Efesus 4:1-2, Paulus mendorong kita untuk hidup dalam dalam kesabaran dan dalam Kolose 3:12 kita diperintahkan untuk mengenakan kesabaran. Jelaslah bagi Paulus (yang perlu saya ingatkan, tidak hanya sedang mengekpresikan pendapat pribadinya tetapi sedang menulis di bawah pimpinan Roh Kudus) kualitas kesabaran adalah kebajikan yang harus ditanamkan. ${ }^{20}$

Ketika petani tersebut mulai menanam tetap bersabar dan tekun untuk membersihkan rumput-rumput yang mengganggu, memupuk untuk memberi pertumbuhan padi tersebut dan juga menjaga dari serangan hama padi, dan juga mengatur pengairannya. Padahal petani ini belum tentu tahu hasilnya kelak bagaimana tanaman padinya, tetapi petani itu tetap tekun mengerjakan bagiannya dengan sabar menantikan hasilnya.

Kalau dilihat dari proses ini mungkin banyak orang tidak mau melakukannya karena hasilnya saja belum pasti dan tidak cepat bisa dilihat, bahkan kemungkinan juga tidak mendapatkan hasil apapun. Paulus mengajarkan gambaran petani kepada Timotius yaitu tentang karakter petani yang sabar dan tekun sekalipun belum tahu hasilnya seperti apa, yang penting tekun melakukan prosesnya terus-menerus dan tidak pantang menyerah sekalipun belum tahu hasilnya seperti apa. Kata tekun identik dengan setia, Bridges menjelaskan tentang orang setia dan disejajarkan dengan kisah Daniel sebagai berikut:

Orang yang setia adalah orang yang dapat diandalkan dalam segala hubungan; yang sama sekali jujur dan beretika dalam segala urusannya. Tentang Daniel dikatakan bahwa lawan-lawannya "mencari alasan dakwaan terhadap Daniel dalam hal pemerintahan, tetapi mereka tidak mendapat alasan apa pun atau sesuatu kesalahan, sebab ia setia dan tidak didapati sesuatu kelalaian atau sesuatu kesalahan padanya ${ }^{21}$

Mungkin juga akan memiliki murid atau anak rohani yang tidak mudah untuk diarahkan dan diajar, tetapi harus tekun karena belum tahu bagaimana hasil akhirnya.

Inilah yang Paulus inginkan kepada Timotius untuk terus tekun mengerjakan bagian pelipatgandaan ini,sekalipun belum melihat hasilnya. Karena proses pelipatgandaan ini seperti proses merawat seorang anak bayi sampai menjadi dewasa dan berhasil mandiri. Perlu banyak bersabar dan harus terus tekun sampai anak tersebut menjadi dewasa dan mandiri, sekalipun tidak jarang orang tua dibuat jengkel oleh anak-anak. Oleh sebab itu Timotius diingatkan oleh Paulus untuk memiliki karakter petani tersebut yang terus tekun pada proses sampai pada waktunya melihat hasil sekalipun harus melewati suka dan duka.

\section{Menjadi Seperti Seorang Olahragawan}

Bridges mengatakan seperti berikut:

\footnotetext{
${ }^{20}$ Jerry Bridges, Respectable Sins, ( Bandung: Pionir Jaya, 2009), 134

${ }^{21}$ Jerry Bridges, Hidup Yang Berbuah, (Bandung: Pioner Jaya, 2009, 130
} 
Penguasaan diri adalah ciri karakter hakiki orang saleh yang memampukan dia taat pada perkataan Tuhan Yesus, "setiap orang yang mau mengikut Aku harus menyangkal dirinya, memikul salibnya setiap hari dan mengikut Aku" (lukas 9:23). Mustahil menjadi pengikut Yesus tanpa tekun memperhatikan anugerah penguasaan diri dalam hidup kita. ${ }^{22}$

Seorang olahragawan terkenal dengan kedisiplinannya dan juga semangat yang pantang menyerah ketika menghadapi tantangan. Untuk menjadi juara dia harus berlatih keras dan terus menerus dalam bidang olahraga yang ditekuninya, sebagai contoh kalau dia seorang pelari, maka sebelum tiba perlombaan lari tersebut dia harus disiplin untuk berlatih terus menerus berlari, mulai dari bangun pagi sampai sore akan terus latihan berlari, bahkan tiap hari pekerjaannya adalah berlari.

Secara manusia pasti mengalami kebosanan karena setiap hari mengerjakan pekerjaan yang sama terus yaitu harus terus berlari, tetapi kedisiplinan berlatih inilah yang akhirnya mengalahkan rasa bosan dan juga kedisiplinan ini juga yang akan membuat atlet ini berhasil menjadi juara. Dan bukan itu saja rupanya harus perlu juga mentaati aturan yang berlaku dalam pertandingan nantinya. Candawasa mengutip bahwa "sungguh kita tidak dapat mengontrol $10 \%$ hal -hal yang terjadi. Tapi yang $90 \%$ lagi ditentukan oleh reaksi kita.“23 Ini berarti seorang atlet juga harus menguasai diri untuk jujur mengikuti aturan yang ada dan tidak berbuat curang dengan mengusai lintasan orang lain sehinga menghalang-halangi lawannya untuk bisa berlari secara leluasa.

Palulus mau mengajarkan Timotius untuk memiliki disiplin yang tinggi yang berarti juga memiliki penguasaan diri sebagai orang yang akan melipatgandakan, sekalipun kadang-kadang hal tersebut akan membosankan. Sebagai contoh memiliki disiplin dalam berdoa, membaca Firman, dan yang lainnya, dan disiplin untuk mengatur waktu-waktu dalam mengajar dan melipatgandakan. Semangat yang pantang menyerah dalam menghadapi banyak masalah serta jujur dalam melakukan pelayanan. Memang bukanlah hal yang mudah untuk bisa mendisiplin diri, memiliki semangat yang pantang menyerah dan jujur dalam hal-hal rohani, karena selalu ada rintangan, tetapi Paulus sudah mengingatkan hal tersebut kepada Timotius, dan memberi teladan kepada Timotius.

\section{Teladan untuk melipatgandakan menurut II Timotius 2:8-13}

Paulus juga memberikan teladan dalam melakukan pelipatgandaan kepada TImotius bukan hanya memberikan perintah kepada Timotius. Teladan tersebut bukan hanya oleh Paulus tetapi oleh Tuhan Yesus sendiri.

\section{Teladan Yesus Kristus}

Paulus mengingatkan dalam ayat 8 kepada Timotius, bahwa Yesus Kristus yang telah bangkit dari antara orang mati, itulah yang diberitakannya. Lalu teladan apa yang bisa diteladani dari Tuhan Yesus? Karena kasihNya juga Yesus melakukan pengorbanan sehingga akhirnya Dia rela juga disalib untuk menebus juga orang yang telah

\footnotetext{
${ }^{22}$ Ibid, hal 152

${ }^{23}$ Yohan Candawasa, MendapatkanMu dalam Kehilanganku, (Bandung: MItra Pustaka, 2009), 31
} 
menyalibkanNya, karena tujuan penebusan Yesus adalah untuk semua orang. Ada satu hal yang menjadi teladan sekaligus juga pesan Yesus yang telah dan berharap terus akan dilakukan oleh semua orang yang percaya di dunia ini, yaitu teladan untuk melipatgandakan seperti yang tertera dalam Matius 28:19-20, yang lebih dikenal dengan Amanat Agung dengan perintah untuk menjadikan semua bangsa muridNya. ${ }^{24}$ Tuhan Yesus tidak hanya memberikan perintah tersebut tetapi juga sudah memberikan teladan dalam melakukan menjadikan murid, terbukti dengan 12 murid yang selalu bersama sama dengan Dia. Yesus memberikan pengajaran lewat kehidupanNya secara langsung kepada kedua belas murid lewat peristiwa-peristiwa yang dilakukan oleh Yesus sendiri, baik secara teori yaitu pengajaran dan praktek lapangan, ketika melayani orang-orang yang kelaparan, memberi makan, ketika ada orang sakit disembuhkan, bahkan ketika ada orang mati Yesus membangkitkannya.

Lyne mengatakan :

Dia tidak mendirikan "Sekolah Alkitab Kapernaum", tetapi mengutus mereka untuk menyembuhkan orang sakit, mengusir setan dan memberitakan Kerajaan Allah. Lalu mereka harus kembali kepadaNya untuk memberi laporan tentang apa yang telah mereka perbuat. $^{25}$

Yesus bisa melakukan apapun untuk menjadikan semua orang percaya kepadaNya, tetapi Yesus tidak melakukanNya. Dan hal tersebut terbukti melalui 12 murid Tuhan Yesus, sekalipun yang satu berkhianat dan akhirnya memilih mati gantung diri, yaitu Yudas Iskariot. Tetapi melalui kesebelas murid yang lain maka berkembang murid-murid ini dengan melihat metode Yesus yang telah dilihat, diterima dan dipraktekannya akhirnya menjadi 3000 orang percaya pada hari pentakosta dan akhirnya meluas kalau dilihat di Kisah Para Rasul melalui kehidupan mereka setiap hari Tuhan Yesus menambahkan jumlah orang percaya.

\section{Teladan Paulus}

Paulus sendiri juga menyebutkan dalam pesannya kepada Timotius yaitu bahwa "karena pemberitaan Injil inilah Paulus harus dibelenggu seperti seorang penjahat." Ini memberikan indikasi bahwa keberadaan Paulus disamakan dengan seorang penjahat, padahal yang Paulus lakukan adalah hal yang sangat mulia tetapi dianggap yang dilakukan adalah sama dengan yang dilakukan oleh penjahat. Mengapa hal itu terjadi? karena apa yang Paulus lakukan membuat banyak orang mengerti dan percaya kapada Yesus, sehingga banyak pihak-pihak juga yang merasa dirugikan dan juga orang-orang yang telah terkemuka waktu itu terutama para ahli taurat dan orang Farisi merasa kehilangan banyak pengikut, sehingga kesempatan tersebut menjadi momen untuk mereka manfaatkan membelenggu Paulus karena pengajarannya.

Tetapi Paulus juga memberikan teladan dengan mengatakan bahwa dia tetap sabar menanggungnya, dengan tujuan supaya orang-orang pilihan Allah mendapatkan

\footnotetext{
${ }^{24}$ Dwiraharjo, "Kajian Eksegetikal Amanat Agung Menurut Matius 28 : 18-20."

${ }^{25}$ Peter Lyne, Peralihan Tongkat, (Jakarta : Yayasan Pekabaran Injil Immanuel, 2002), 26
} 
keselamatan tersebut. Seandainya Paulus tidak memiliki kesabaran dalam menanggung bagian tersebut maka dia pasti akan sangat benci kepada orang-orang yang telah menyebabkan dia terbelunggu dan juga pasti akan mengutuki mereka. Dan akhirnya karena hal tersebut maka Paulus tidak bisa memberitakan Injil kepada mereka .

\section{PEMBAHASAN}

\section{Srategi Pelipatgandaan}

Paulus memakai strategi dengan cara memuridkan terlebih dahulu Timotius baik secara langsung dengan beberapa kali mengajak Timotius dalam perjalanan misinya. Selain itu berdasarkan 2 Timotius 2:2 ketika Paulus sedang memuridkan Timotius, Paulus sudah memiliki gambaran kedepan atau yang sekarang lebih dikenal dengan visi melipatgandakan sampai empat generasi, artinya sampai Paulus memiliki cicit rohani, seperti juga yang dijelaskan oleh Herdy sebagai berikut :

Dari contoh Paulus dan Timotius itu, ada empat generasi atau empat pihak yang mengalami pelipatgandaan. Pertama-tama. Paulus melatih dan memberikan wewenang kepercayaan kepada muridnya, TImotius. Selanjutnya, Timotius melatih dan memberikan kepercayaan kepada orang lain yang dapat dipercaya. Setelah itu, orang lain yang dapat dipercaya tersebut akhirnya menolong orang lain berikutnya untuk bertumbuh. Dengan kata lain proses pemuridan dan mentoring tersebut jangan berhenti pada satu fase generasi, tetapi harus dilakukan terus ke generasi berikutnya dengan proses pelatihan dan pemberian wewenang kepercayaan. ${ }^{26}$

Dengan demikian pelipatgandaan jemaat berdasarkan 2 Timotius 2:1-13, adalah bagaimana menjadikan mereka murid Kristus seperti yang telah Paulus lakukan kepada Timotius sebagai anak rohaninya sekaligus muridnya. Pemimpin menyiapkan jemaat menjadi murid sebagai generasi yang kedua yang lebih kuat, dan menjadikan murid yang mendengar dengan saksama kepada mentornya, membekali dengan menyiapkan karakter murid yang memiliki ketangguhan serta ketaatan seperti seorang prajurit kepada komandannya yang dalam hal ini pastilah komandannya adalah Tuhan Yesus Kristus, dan juga memiliki karakter seperti seorang petani yang tekun dan sabar, serta seperti seorang olahragawan yang disiplin, jujur dan pantang menyerah.

Setelah itu barulah murid tersebut dipersiapkan untuk mempercayakan kepada orang lain lagi yang berarti menyiapkan generasi kedua sama seperti bagaimana generasi kedua tadi dipersiapkan maka barulah generasi ketiga tadi yang memiliki kemampuan untuk mengajar akan melakukan lagi pada generasi yang keempat. Tetapi yang tidak boleh dilupakan ketika para murid menghadapi tantangan teladan mereka adalah teladan Tuhan Yesus dan Paulus yang telah melakukannya.

\section{Relevansi bagi pertumbuhan jemaat masa kini}

Strategi Pelipatgandaan ini sangat menolong untuk mempersiapkan kepemimpinan yang akan datang dan bukti kepemimpinan yang berhasil yaitu bisa melahirkan pemimpin baru, seperti yang diungkapkan oleh Herdy:

\footnotetext{
${ }^{26}$ Herdy N. Hutabarat, Mentoring dan Pemuridan, (Bandung: Kalam HIdup, 2011), 200-201
} 
Salah satu bukti kepemimpinan yang berhasil adalah ketika pemimpin itu sudah tidak aktif lagi (mengemban tugas yang lain, sakit, sudah terlalu tua dan lemah, atau meninggal dunia). Tetapi organisasinya berjalan terus dengan baik karena ia telah melatih dan membina orang lain yang siap menggantikan dirinya. Ada penyerahan tongkat estafet sehingga organisasinya tidak sempat mengalami keguncangan atau kemunduran akibat terjadinya krisis kepemimpinan. ${ }^{27}$

Lalu bagaimana langkah-langkah atau strategi pelipatgandaan yang harus di terapkan supaya jemaat bisa bertumbuh.

\section{Menjadi Murid}

Jemaat harus dijadikan kuat lebih dahulu caranya dengan meminta sendiri kekuatan itu sendiri kepada Tuhan. Inilah bagian dari proses menjadi murid yaitu bagaimana jemaat masa kini harus tetap kuat dan tangguh ketika menghadapi masalah yang menimpa kepadanya. Untuk menjadi kuat seseorang harus menjalani latihan-latiihan dan tempaantempaan dalam berbagai bidang kehidupan, dan seharusnya ketika mengalami masalah manusia yang percaya berdoa seperti yang Yesus lakukan dan ini merupakan doa yang paling sukar, seperti yang dinyatakan oleh John B. Pearrell sebagai berikut :

Doa yang paling sukar bukannya "Ya Tuhan, berilah aku nasib yang baik dan juahkanlah aku dari segala bahaya." Atau ya Tuhan, berilah aku ini atau itu dan buatlah begini atau begitu." Doa yang paling sukar ialah yang dinaikkan Kristus di Getsemani, "Ya Bapaku, jikalau sekiranya mungkin, biarlah cawan ini lalu daripada$\mathrm{Ku}$, tetapi janganlah seperti yang Kukehendaki, melainkan seperti yang Engkau kehendaki" (Mat. 26:39) ${ }^{28}$

Demikian juga dengan jemaat Tuhan, sekali lagi untuk menjadi kuat tetap selalu tangan Tuhan yang memegang dan menyertai, tetapi untuk menjadi kuat tersebut jemaat juga memerlukan asupan makanan, dan makanan yang diberikan yaitu pengajaranpengajaran dan teladan yang dilihat dari pemimpinya atau gembala. Tetapi yang tidak bisa diabaikan juga yang menjadikan jemaat kuat adalah setiap hal yang menempa dalam kehidupan jemaat tersebut.

Semakin banyak masalah yang dihadapi maka sesungguhnya jemaat sedang diajari secara tidak langsung oleh Tuhan untuk menjadi kuat, misalnya ketika mengalami masalah ekonomi dalam mengiring Kristus, apakah jemaat mampu bertahan untuk tetap mengiring Tuhan. Oleh sebab itu peran pengajaran dan teladan dari gembala atau mentor sangatlah penting dalam menjadikan murid.

Pemuridan membutuhkan sebuah pembimbingan dan pengajaran. Bukan hanya pengajaran yang bersifat teoritis saja berdasarkan Firman Tuhan, tetapi juga pembimbingan dari gembala atau mentor justru juga tidak bisa diabaikan karena pembimbingan tersebut yang menjadikan hubungan semakin dekat seperti orang tua dengan anaknya. Chan memberikan penjelasan kata murid adalah sebagai berikut:

Kata "murid" merujuk pada orang-orang yang belajar atau magang. Murid-murid pada zaman Yesus akan mengikuti seorang "rabi" (yang artinya guru) ke manapun ia

\footnotetext{
${ }^{27}$ Herdy N Hutabarat, Mentoring dan Pemuridan, (Bandung : Kalam Hidup, 2011), hal 303-304

${ }^{28}$ Tim Penyusun, Pola Hidup Kristen, (Malang: Gandum Mas, 2002), hal 500
} 
pergi, belajar dari pengajaran rabi itu, dan berlatih untuk melakukan yang dilakukan rabi itu. pada dasarnya, dari arti katanya secara harafiah, seorang murid adalah seorang pengikut. Menjadi murid Yesus adalah sederhana menaati panggilan-Nya untuk mengikuti. ${ }^{29}$

Pemuridan yang terjadi seperti orang tua dengan anak ini berarti, pembimbingan dan pengajaran yang terjadi secara langsung, artinya keduanya saling ditajamkan dan dilatih baik dari pihak anak dan pihak orang tua.

Jika seorang gembala atau mentor berperan menjadi orang tua rohani bagi muridnya maka tidak mungkin ketika sang anak salah waktu dalam proses penguatan akan langsung diputuskan hubungan antara orang tua dengan anak. Dalam hal ini orang tua sedang belajar untuk memiliki kesabaran dan terus tekun dalam membimbing sang anak, dan bagi sang anak atau murid sedang belajar untuk melihat teladan bagaimana menjadi orang tua dan juga belajar mengerti untuk introspeksi serta dengan rendah hati mengakui kesalahan yang telah dilakukan dan siap memperbaiki kesalahan tersebut sesuai dengan pengajaran yang akan diberikan oleh orang tua rohaninya.

Chan menulis sebagai berikut:

Ketika Yesus memanggil murid-murid yang pertama, mereka mungkin tidak tahu kemana Yesus akan membawa mereka, atau apa dampaknya bagi kehidupan mereka, tetapi mereka tahu apa artinya mengikuti. Mereka menerima panggilan Yesus secara harafiah, dan mulai mengikuti kemanapun Yesus pergi, dan melakukan apapun yang Yesus lakukan. ${ }^{30}$

Tuhan Yesus selalu memberi pengajaran kepada mereka dan memberikan teladan kepada mereka, sehingga murid-murid ini boleh mengerti dan melakukannya. Tetapi pembimbingan yang Tuhan Yesus lakukan juga luar biasa, Yesus selalu memberi kesempatan bertobat kepada para murid yang melakukan kesalahan, seperti halnya yang nampak kepada Petrus, walaupun sudah menyangkal tetap Tuhan memberi kesempatan untuk bisa memperbaiki kesalahannya dan akhirnya Petrus bisa menjadi murid Yesus yang memiliki dedikasi yang baik untuk memberikan hidupnya bagi Yesus.

Oleh sebab itu jemaat harus dijadikan murid bukan hanya jemaat yang setia untuk beribadah, tetapi juga murid yang diberikan pengajaran yang akan menambah jemaat menjadi kuat dan juga diberikan pembimbingan secara pribadi melalui waktu waktu non formal di luar acara pengajaran, mungkin hal tersebut melalui makan bersama, waktu santai bersama sama pergi jalan ataupun waktu bersantai dirumah jemaat dan waktu-waktu yang bisa membuat jemaat terbuka dan menjadi akrab seperti anak dengan orang tuanya.

Untuk menjadikan jemaat menjadi seorang murid yang kuat maka harus memiliki karekter seperti seorang prajurit yang dikenal dengan ketaatannya, ketaatan yang dimaksud jelas membawa murid ini taat kepada apa yang Tuhan Yesus kehendaki, yaitu taat terhadap Amanat Agung yang Tuhan Yesus perintahkan tanpa berfikir hal-hal yang akhirnya akan

\footnotetext{
${ }^{29}$ Francis Chan, Multiply, (Yogyakarta: Katalis, 2017), 16

${ }^{30}$ Ibid
} 
menjadikan tawar hati, yang penting siap laksanakan untuk taat terhadap perintah tersebut, jika dalam bahasa Paulus tidak memusingkan dengan perkara-perkara penghidupannya.

Jemaat yang siap menjadi murid juga harus diajar memiliki karakter yang seperti petani yang memiliki karakter tekun dan sabar menanti hasil dari apa yang ditanamnya, demikian juga jemaat yang siap menjadi murid harus memiliki ketekunan dan kesabaran, tekun artinya dalam mengerjakan apa yang harus dikerjakan sesuai dengan kehendak Tuhan dan sesuai dengan talenta dan karunia yang dipercayakan kepadanya sekalipun banyak tantangan dan masalah yang akan dialaminya harus tetap tekun dan sabar berarti bersabar menunggu hasil menuai, ini berarti memberikan indikasi bahwa apa yang kita tabur tidak instan langsung dituai. Tetapi jika sabar maka akan melihat hasil tuaian tersebut, artinya orang-orang baru yang akan disiapkan untuk juga menjadi penuai-penuai berikutnya.

Jemaat yang siap menjadi murid juga harus diajar memiliki karakter seperti olahragawan yang terkenal dengan kedisiplinannya untuk terus berlatih dalam bidang yang ditekuninya serta semangat pantang menyerah dan jujur tidak berlaku curang tetapi mematuhi aturan main waktu bertanding jika ingin menjadi juara. Demikan juga seorang murid harus terus melatih dengan disiplin bagaimana menjadi murid Kristus, harus terus disiplin dalam melatih membaca Firman sehingga akhirnya makin memiliki dasar yang kuat karena dasarnya Firman Tuhan dan juga akhirnya menghidupi Firman itu, karena ada masanya akan ada gunanya disiplin membaca Firman ini akan diuji yaitu ketika tantangan dan masalah datang maka latihan menghidupi Firman ini akan berguna, karena aturan main untuk bisa menang dari masalah dan tantangan tersebut harus belajar Firman Tuhan dan menghidupinya.

Demikian juga sebagai murid Kristus harus terus menjaga disiplin komunikasi dengan Tuhan Yesus lewat doanya sehingga akhirnya menjadi kenal Tuhan Yesus dengan baik dan menjadi sahabatNya dan anakNya.

\section{Jemaat Menjadi Murid yang Siap Pergi}

Chen menyatakan seperti berikut :

Menjadi pembuat murid berarti anda mulai memandang orang-orang dalam hidup anda secara berbeda. Setiap orang dalam hidup anda diciptakan segambar dengan Allah, dan Yesus memanggil setiap orang untuk mengikut Dia. Allah telah menempatkan orang-orang ini dalam hidup anda agar anda dapat melakukan yang dapat anda lakukan untuk mempengaruhi mereka. Mengikut Yesus berarti anda mengajar orang lain untuk mengikut Yesus. ${ }^{31}$

Untuk pergi berarti harus siap artinya ada bekal yang dibawa sehingga tidak mengalami banyak kesulitan. Bekal tersebut berarti dasar-dasar pengajaran yang telah ditanamakan dalam diri jemaat yang telah menjadi murid dan segala teladan yang telah dilihat dari mentor atau gembala atau bapak rohaninya. Dan juga jemaat yang menjadi

\footnotetext{
${ }^{31}$ Ibid, 36
} 
murid seharusnya adalah sudah cukup kuat, karena ketika mempercayakan atau pergi jemaat yang siap menjadi murid membutuhkan hal ini

Demikan juga dengan seorang petani yang akan bersiap untuk pergi menuai padi ke sawahnya pasti juga sudah bersiap dengan segala persiapannya dan peralatannya yang akan dipakai untuk menuai padi di sawahnya, mulai dari peralatan dan perbekalan perlu disiapkan supaya rencana pekerjaan yang telah direncanakan, supaya tidak kehilangan waktu menuai dan padi yang sudah menguning tidak menjadi rusak.

\section{Menjadi Murid yang Pergi untuk Menjadikan Murid}

Tentunya ada persyaratan atau kompetensi utama yang harus dimiliki oleh seorang pembuat murid, seperti Herdy menyatakan sebagai berikut:

Jawaban dan ulasannya adalah sebagai berikut (saya sebut ini sebagai "lima persyaratan utama"). Memiliki hati Bapa; memiliki panggilan dan motivasi yang kuat; berjiwa melayani dan bukan memerintah; tetap tekun dan tidak mudah menyerah; mau menjadi teladan, mau belajar, dan bertumbuh terus-menerus. ${ }^{32}$

Demikan juga tahap berikutnya ketika jemaat yang sudah menjadi murid yang telah pergi maka murid tersebut telah siap untuk menjadikan murid lain lagi yang bisa dipercayai dan cakap mengajar orang lain lagi. bagaimana murid tersebut bisa melakukan hal ini? Murid ini bisa melakukan dengan pola yang sama yang pernah dialami oleh jemaat yang dimuridkan tadi. Oleh sebab itu tidak bisa jemaat melipatgandangakan jika jemaat tersebut tidak pernah memiliki pengalaman menjadi seorang murid. Karena proses menjadi seorang murid inilah yang akan memberikan jemaat tersebut bisa menjadikan murid yang lain lagi sesuai dengan tahapan-tahapan yang dialaminya tetapi dengan cara murid tersebut.

\section{KESIMPULAN}

Paulus memberikan perintah kepada Timotius dalam II Timotius 2:2, untuk berani mempercayakan apa yang telah didengar dari Paulus kepada orang-orang yang dapat dipercayai dan juga cakap mengajar orang lain lagi. pada perintah ini terlihat tentang strategi pelipatgandaan yang diterapkan Paulus kepada Timotius kemudian dari Timotius sebagai generasi kedua kepada generasi ketiga dan selanjutnya generasi ketiga kepada generasi keempat. Selain hal tersebut juga sebagai murid, Paulus mengingatkan kepada Timotius untuk memiliki karakter sebagai seorang prajurit yang terkenal dengan karakter ketaatannya. Timotius juga harus memiliki karakter seperti seorang olahragawan yang dikenal dengan "disiplin" dan tidak boleh curang. Timotius sebagai seorang murid harus memiliki karakter seperti seorang petani yang terkenal dengan "kesabaran dan ketekunannya."

Setelah Timotius menjadi murid maka Paulus memeberikan perintah supaya Timotius mengajarkan lagi, bagian ini merupakan sebuah perintah untuk pergi dalam strategi pelipatgandaan, pergi untuk mengajarakan kembali apa yang telah didapat dari orang tua rohani atau mentornya, juga pergi untuk membimbing orang lain lagi, supaya mereka juga

\footnotetext{
${ }^{32}$ Herdy N. Hutabarat, Mentoring \& Pemuridan, (Bandung: Kalam Hidup, 2011), 216
} 
memiliki karakter seperti seorang prajurit yang selalu taat kepada Tuhan Yesus dan karakter seperti seorang olahragawan yang disiplin dengan waktu berlatih dan tidak pantang menyerah dalam segala kondisi dan keadaan tetapi terus berjuang samapai garis akhir dalam melakukan panggilan sebagai murid Kristus dan juga harus jujur tidak boleh curang dalam melayani, serta juga karakter seperti petani yang selalu sabar dan tekun. Tekun dan sabar dalam mengajar dan membimbing orang lain, serta sabar juga untuk menanti hasil yang dari Tuhan Yesus.

Ketika proses mengajar inilah Paulus juga menasihatkan kepada Timotius untuk memilih juga orang yang akan disiapkan menjadi murid yang berikutnya atau dengan kata lain melipatgandakan murid lagi dengan memiliki kriteria yang juga cakap mengajar orang lain lagi, berarti ada proses memilih yang harus dilakukan oleh Timotius waktu pergi atau sambil mengajar dari sekian orang yang diajar, untuk bisa mengenal karakter dan memilih manakah dari orang-orang tersebut yang memang bisa dipercayai dalam proses pengajaran dan pembimbingan dan juga memiliki kecakapan untuk mengajar orang lain lagi. jika dalam proses belajar mengajar di sekolah maka dianggap lulus dalam seleksi atau ujian sekolah.

Setelah didapat orang tersebut maka Timotius akan lebih berfokus untuk kembali memuridkan orang ini untuk kemudian dijadikan murid generasi kedua lagi yang akan disiapkan untuk pergi mengajar lagi dan kemudian melakukan hal yang sama untuk memilih calon murid dan setelah mendapatkannya maka juga akan focus untuk memuridkan lagi untuk pergi mengajar dan memuridkan orang lain lagi menjadi murid genrasi ketiga, demikian siklus ini akan terus bergulir sampai generasi yang keempat dan terjadi yang disebut dengan pelipatgandaan murid.

Strategi yang dipakai dalam pertumbuhan jemaat juga seharusnya melakukan seperti apa yang Paulus kerjakan dalam upaya pelipatgandaan murid. Artinya jemaat bukan hanya dijadikan penonton atau penikmat acara ibadah saja tetapi jemaat supaya mengalami pertumbuhan juga harus dilipatgandakan menjadi murid yang siap pergi untuk menjadikan murid lagi, inilah pola pelipatgandaan.

Pola pelipatgandaan inilah yang bisa diadop dalam jemaat untuk melipatgandakan murid-murid Tuhan Yesus, yaitu pola menjadi murid yang kemudian menjadi murid yang siap pergi dan menjadi murid yang pergi untuk memuridkan lagi sampai generasi yang keempat. Tahap pertama berarti jemaat harus dijadikan murid, ini tugas siapa untuk melakukannya, tentunya tugas gembala jemaat setempat untuk menjadikan jemaatnya murid, lalu bagaimana caranya tidak ada cara lain dengan melakukan pengajaran dan pembimbingan kepada jemaatnya, tentunya pengajaran tersebut bentuknya bisa khotbah, baik melalui ibadah minggu atau melalui bentuk pendalaman Alkitab dalam ibadah rumah tangga. Dalam proses inilah gembala akan memilih jemaat yang siap untuk dimuridkan dengan kriteria seperti yang Paulus ajarkan yaitu yang dapat dipercaya dan cakap mengajar orang lain. Baru proses berikutnya memuridkan jemaat yang telah siap tersebut dengan pengajaran dan pembimbingan dan membekali dengan karakter-karakter yang harus 
dimiliki seperti prajurit yang taat, seperti olahragawan yang disiplin dan pantang menyerah dan juga jujur, serta seperti seorang petani yang sabar dan tekun mengerjakan dan menanti hasilnya. Hal tersebut bisa dialkukan secara fleksibel untuk waktu dan tempat pertemuan.

Setelah jemaat sudah menjadi murid sebagai generasi kedua yang mengusai pengajaran dan memiliki karakter seperti diatas maka saatnya jemaat yang sudah murid generasi kedua tersebut diutus untuk pergi mengajarkan apa yang telah dia peroleh kepada teman-teman jemaat yang lain lagi dan tentunya juga akan bersiap memilih dari temanteman jemaat yang sudah diajar tadi untuk dijadikan murid kembali dengan kriteria yang sama ketika dia dipilih menjadi murid, tetapi orang tua rohani atau mentor tetap harus memberikan pendampingan jika sewaktu waktu murid generasi kedua ini memerlukan bantuan dan juga terus mendukung dalam doa. Barulah setelah terpilih murid generasi ketiga maka tugas murid generasi kedua berubah menjadi orang tua rohani atau mentor yang berfungsi mengajar murid generasi ketiga dan mendampingi sambil menekankan kembali karakter karakter yang harus dimiliki seorang yang akan memuridkan orang lain lagi atau teman jemaat yang lain menjadi murid generasi keempat. Demikian juga terus dengan tekun dan sabar memberikan bimbingan seperti orang tua dengan anaknya, sampai akhirnya menjadi murid generasi yang kedua. Dan setelah murid generasi yang kedua ini telah siap maka juga kan melakukan hal yang sama untuk melipatgandakan murid generasi yang ketiga dan berarti peran murid generasi kedua berubah peran menjadi orang tua rohani atau mentor bagi generasi ketiga, dan pola pelipatgandaan tersebut akan terus bergulir sampai generasi keempat maka barulah terjadi gerakan secara otomatis tetapi peran pencetak generasi juga penting untuk mendukung dalam doa dan memberikan bantuan yang diperlukan oleh anak-anak rohaninya.

\section{REFERENSI}

Alcon, Randy. Dalam Terang Kekekalan, Yogyakarta: Yayasan Gloria-katalis, 2011. Bridges, Jerry. Hidup Yang Berbuah, Bandung: Pioner Jaya, 2009. Respectable Sins, Bandung: Pionir Jaya, 2009.

Cara Gereja Lokal Dapat Bertumbuh Secara Sehat, available from, http://www.sabda.org/PUBLIKASI/a31-misipenginjilan.blogspot.com. Internet

Candawasa, Yohan. MendapatkanMu dalam Kehilanganku, Bandung: Mitra Pustaka, 2009

Chan, Francis. Multiply, (Yogyakarta: Katalis, 2017), 16

Dwiraharjo, Susanto. "Kajian Eksegetikal Amanat Agung Menurut Matius 28 : 18-20." Jurnal Teologi Gracia Deo 1, no. 2 (2019): 56-73. http://sttbaptisjkt.ac.id/ejournal/index.php/graciadeo.

Hutabarat, Herdy N. Mentoring \& Pemuridan, Bandung: Kalam Hidup, 2011

Lyne, Peter. Peralihan Tongkat, Jakarta: Yayasan Pekabaran Injil Immanuel, 2002.

Maniku, Guntar. Buku ledakan pemuridan di Gereja Lokal, 3

Morton, Scott. Pemuridan untuk semua orang, Yogyakarta: Yayasan Gloria, 2011. . Bahan Amanat Agung dalam perspektif Multiplikasi Pribadi, 7

Siahaan, Harls Evan R. "Aktualisasi Pelayanan Karunia Di Era Digital." EPIGRAPHE: Jurnal Teologi dan Pelayanan Kristiani 1, no. 1 (2017): 23-38. www.stttorsina.ac.id/jurnal/index.php/epigraphe. 
Sutanto, Hasan. Perjanjian Baru Interlinier Yunani-Indonesia, Jakarta: LAI, 2003

Tim Penyusun, Pola Hidup Kristen, Malang: Gandum Mas, 2002

Tenney, Merrill C. Survei Perjanjian Baru, Malang: Gandum Mas, 2001.

Warren, Rick. Pertumbuhan Gereja Masa Kini, Malang: Gandum Mas, 1995.

White, John. The Fight, Yogyakarta: Yayasan Gloria, 2011.

Wiryadinata, Halim. "Mission And Evangelism : African Context." KURIOS (Jurnal Teologi dan Pendidikan Agama Kristen) 3, no. 1 (2015): 1-11.

http://www.sttpb.ac.id/e-journal/index.php/kurios. 